\title{
Soils of Seabee Hook, Cape Hallett, northern Victoria Land, Antarctica
}

\author{
ERICA H. HOFSTEE ${ }^{1}$, MEGAN R. BALKS ${ }^{1 *}$, FIONA PETCHEY ${ }^{2}$ and DAVID I. CAMPBELL ${ }^{1}$ \\ ${ }^{1}$ Department of Earth and Ocean Sciences, University of Waikato, Private Bag 3105, Hamilton, New Zealand \\ ${ }^{2}$ Department of Earth and Ocean Sciences, Waikato Radiocarbon Dating Laboratory, University of Waikato, Private Bag 3105, Hamilton, \\ New Zealand \\ *corresponding author: m.balks@waikato.ac.nz
}

\begin{abstract}
The soils of the Seabee Hook area of Cape Hallett in northern Victoria Land, Antarctica, were mapped and characterized. Seabee Hook is a low-lying gravel spit of beach deposits built up by coastal currents carrying basalt material from nearby cliffs. Seabee Hook is the location of an Adélie penguin (Pygoscelis adeliae) colony which influences the soils with additions of guano, dead birds, eggshells and feathers. A soil-landscape model was developed and a soil association was identified between the soils formed on mounds (relict beach ridges) favoured by penguins for nests (Typic Haplorthel) and the soils in the areas between the mounds (Typic Haplorthel/Typic Aquorthel). Soils formed on the mounds inhabited by penguins contained guano in the upper $50 \mathrm{~cm}$, overlying sub-rounded beach-deposited gravel and sand. Soils between mounds had a thin veneer $(<5 \mathrm{~cm})$ of guano overlying basaltic gravelly sand similar to that in the lower parts of the mound soils. The soils had high concentrations of nitrogen, organic carbon, phosphorus, cadmium, zinc, copper, and increased electrical conductivity, within horizons influenced by penguin guano. Five buried penguin bones were collected from the base of soil profiles and radiocarbon dated. The dates indicate that Seabee Hook has been colonized by penguins for at least 1000 years.
\end{abstract}

Received 15 November 2005, accepted 15 August 2006

Key words: Antarctic soil, carbon dating, guano, Latitudinal Gradient Project, ornithogenic, XRF

\section{Introduction}

Cape Hallett is located in northern Victoria Land, Antarctica. It is a $36 \mathrm{~km}$ long peninsula formed from a basalt shield volcano with a summit of $1740 \mathrm{~m}$ (Harrington et al. 1967). There are a number of basalt volcanoes in the district, and some sedimentary rocks on the northern side of Edisto Inlet (Harrington et al. 1967). Near the end of the Cape Hallett peninsula is a spit named Seabee Hook, (Fig. 1) the location of an Adélie penguin (Pygoscelis adeliae) colony and the site of a USA/NZ base from 1957-73.

Antarctic soils form in ice-free areas, with the largest area in the McMurdo Dry Valleys. Soils within Antarctic penguin colonies are described as ornithogenic, due to the presence of organic materials including, guano, dead birds, feathers and eggshells (Syroechkovsky 1959). Ornithogenic soils have been especially closely studied near the Polish base on King George Island (Pietr et al. 1983, Tatur \& Myrcha 1983, 1984, Myrcha et al. 1985, Tatur \& Barczuk 1985, Tatur 1989, Myrcha \& Tatur 1991, Tatur et al. 1997, Juchnowicz-Bierbasz \& Rakusa-Suszczewski 2002, Tscherko et al. 2003, Zdanowski et al. 2005).

The ornithogenic soils on the Antarctic islands differ from continental ornithogenic soils due to increased liquid water present from rainfall and meltwater in the maritime Antarctic (Myrcha \& Tatur 1991). Continental ornithogenic soils have been studied mostly on and around Ross Island
(Ugolini 1972, Orchard \& Corderoy 1983, Ramsay 1983, Speir \& Cowling 1984, Speir \& Ross 1984, Ramsay \& Stannard 1986, Heine \& Speir 1989, Porazinska et al. 2002) with some research conducted along the northern Victoria Land coast, including Cape Hallett (Harrington \& McKellar 1958, Benes 1960, Claridge 1965, Campbell \& Claridge 1966, McCraw 1967) and also near Casey Station (Roser et al. 1993). Soils in all penguin colonies are generally high in total phosphorus $(\mathrm{P})$, organic carbon $(\mathrm{C})$, and total nitrogen $(\mathrm{N})$ with high electrical conductivity (EC) values and large variations in $\mathrm{pH}$ (Ugolini 1972, Speir \& Cowling 1984, Tatur \& Myrcha 1984, Tatur 1989).

Phosphatised rock was found below the guano layer on King George Island (Tatur \& Barczuk 1985, Tatur 1989, Myrcha \& Tatur 1991), but there have been no reports of phosphatised rock within Antarctic continental ornithogenic soils.

Microbiological activity is higher in ornithogenic soils than in non-ornithogenic soils in Antarctica (Orchard \& Corderoy 1983, Ramsay 1983, Roser et al. 1993, Tscherko et al. 2003, Zdanowski et al. 2005). Increased microbial activity may be expected to increase the numbers of invertebrates found in ornithogenic soils, however Porazinska et al. (2002) found this was not the case on Ross Island.

McCraw (1967) included soil descriptions of the top $10 \mathrm{~cm}$ from an ornithogenic soil, scree soil and beach gravel 


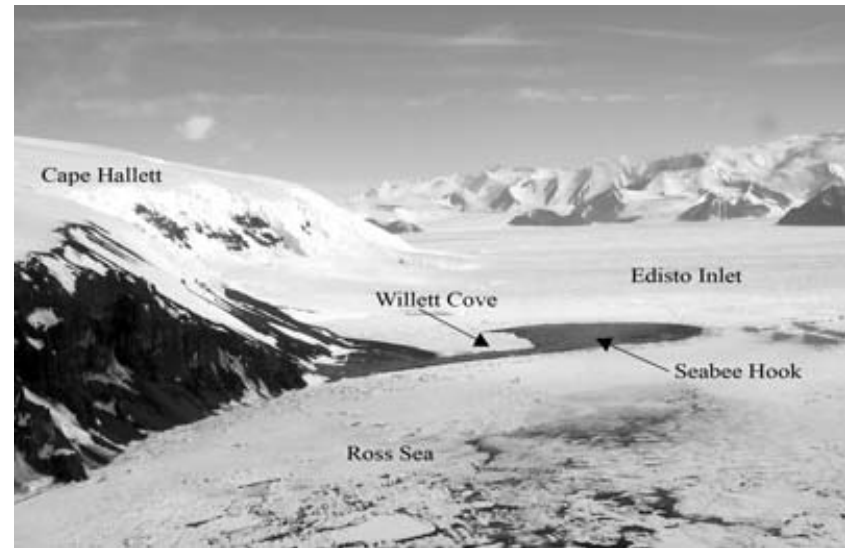

Fig. 1. Key features within the Cape Hallett area (photograph taken in December 2004 looking towards the south).

at Seabee Hook. Soils of the wider Cape Hallett region within Edisto Inlet were described, including scree soils similar to those found at Seabee Hook, by Campbell \& Claridge (1968).

Dates for penguin habitation of $545-5840{ }^{14} \mathrm{C}$ years BP have been reported for abandoned penguin colonies on raised beach ridges from around the Ross Sea region (Hall et al. 2004) and increases in penguin population during times such as the Medieval Warm Period (Baroni \& Orombelli 1994) have been noted. Previously reported dates for currently inhabited penguin colonies in the Ross Sea range from about 1200 to 8000 years (Harrington et al. 1967, Speir \& Cowling 1984, Baroni \& Orombelli 1994).

The Latitudinal Gradient Project (LGP) question to which we are contributing is: "to what extent does soil development (e.g. degree of weathering, carbon content and

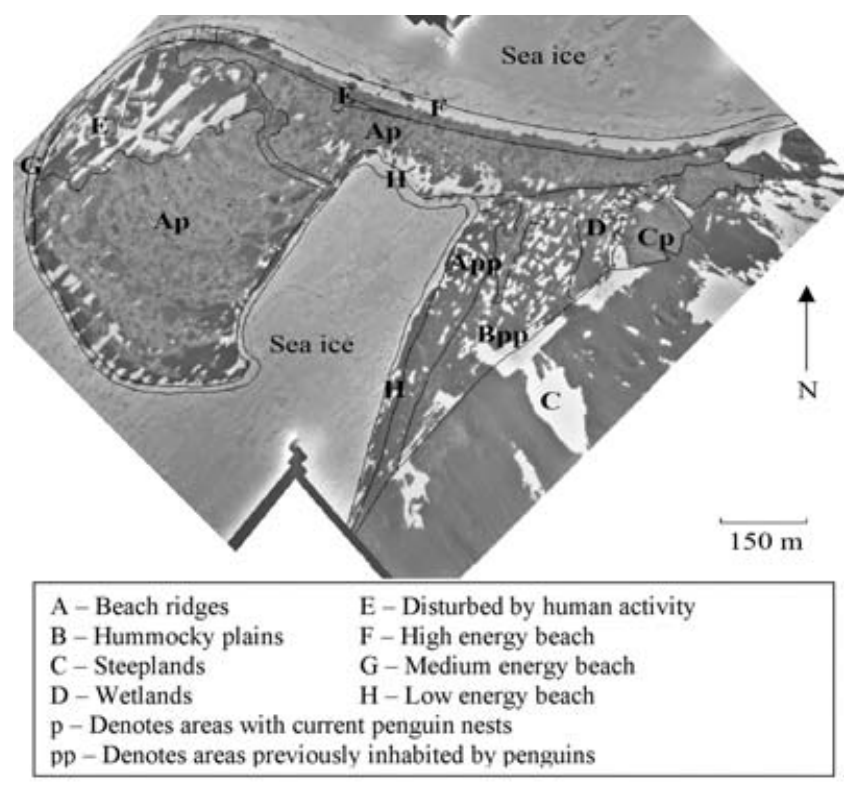

Fig. 2. Physiographic map of Seabee Hook. nutrient accumulation) change with latitude and therefore influence terrestrial ecosystems?" (Howard-Williams et al. 2006). The objective of this paper is to map and characterize the soils at the northern end of the proposed LGP transect for later comparison with the soils in other locations.

\section{The environment}

\section{Physiography}

Seabee Hook is a low-lying area of gravel beach-deposited material, with a maximum elevation of $c .5 \mathrm{~m}$ a.s.l., formed from the gradual build-up of a series of beach ridges (Fig. 2). The current penguin nests are situated on hummocky topography. The mounds are beach ridges that have been accentuated by penguins bringing in stones for nests from nearby areas. Seabee Hook is adjacent to a steep $\left(\sim 30^{\circ}\right)$ slope to the south-east. A moraine forms the lower part of the slope on the southern section of the map. The slope accumulates snowdrifts that provide meltwater to the flat land at the base of the slope during summer, contributing to a wetland area.

Soils at Seabee Hook can be divided into those strongly influenced by penguins (ornithogenic) and those minimally impacted by penguin activity (non-ornithogenic). The ornithogenic soils are found within the penguin nesting area and in areas affected by water runoff from the penguin nesting area. Adélie penguins use stones with a diameter of $3-10 \mathrm{~cm}$ to build nests on already raised areas on Seabee Hook. The raised areas provide some protection from meltwater. It is on the mounds that the penguins deposit most of their guano, leading to development of raised areas with "penguin stones" and guano accumulations, and lowlying areas that comprise gravel and sand, and are depleted of $3-10 \mathrm{~cm}$ size stones as penguins remove them to the
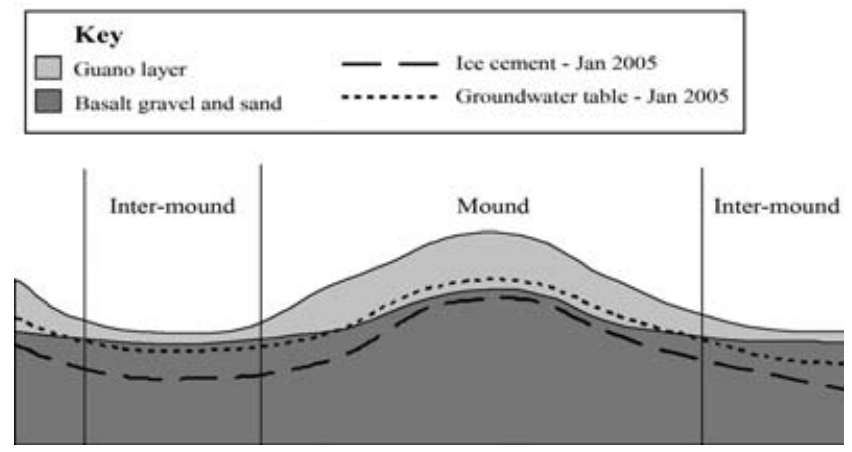

Fig. 3. Soil landscape model showing the soil association relationship between penguin mounds and inter-mounds at Seabee Hook. (Notes: Diagram is not to scale. The depth of guano accumulation on top of mounds was up to about $50 \mathrm{~cm}$ with $0-5 \mathrm{~cm}$ of guano material in inter-mound areas. Mounds varied from about 10 to $30 \mathrm{~m}$ across and the distance between mounds varied from about 10 to $100 \mathrm{~m}$. The height of mounds ranged from about 1 to $3 \mathrm{~m}$ ). 


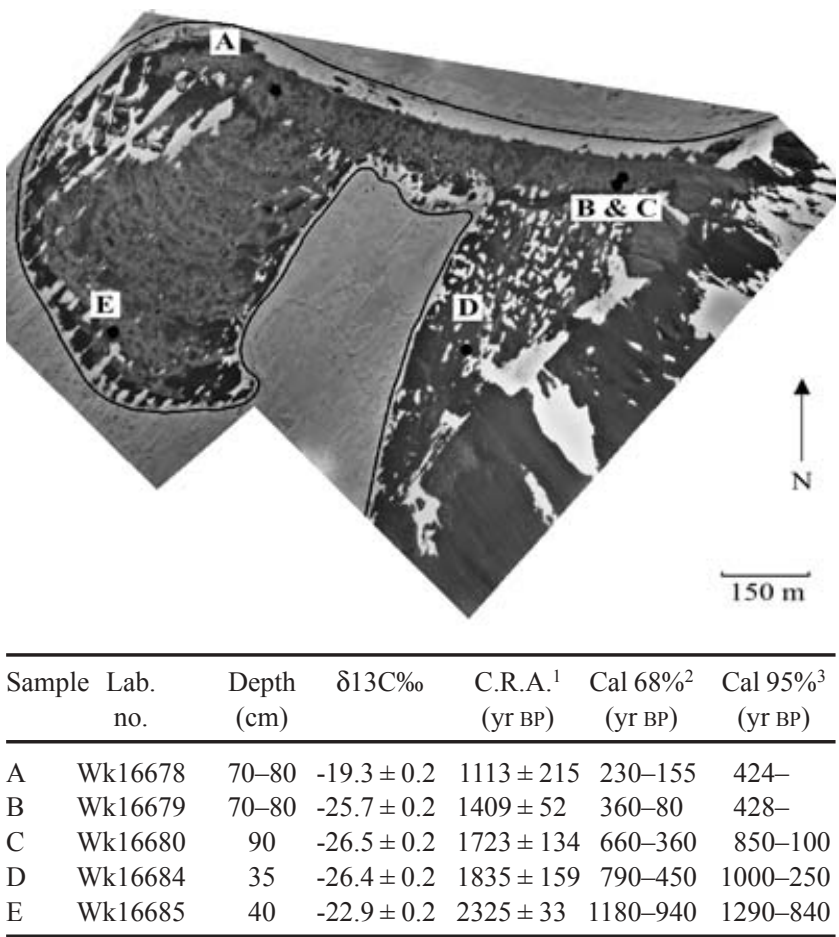

Fig. 4. Locations, depths and radiocarbon dates of Pygoscelis adeliae bones (Wk16679-85) and eggshell (Wk16678).

Radiocarbon ages calibrated using a .R of $811 \pm 102$ years.

mound areas (Fig. 3). The low-lying "intermounds" may have guano within the upper part of the profile, primarily from guano rich water running off nearby mounds.

Mosses (predominantly Bryum subrotundifolium), lichens (11 species), and algae (two species) have been recorded at Seabee Hook (Rudolph 1963, Brabyn et al. 2005). Moss is most abundant in the wetland zone near the base of the cliff (Fig. 2) and contributes to the organic matter present in some soils. Most nests of south polar skua (Catharacta skua maccormicki) are on the scree slope and moraine, with some nests on the beaches near the penguin colony. The skuas add organic matter including guano, feathers, eggshells and penguin remains to the soil near their nest sites.

During the last ice advances, the Ross Sea, including the area currently occupied by Seabee Hook, was filled by ice (Harrington \& McKellar 1958). The grounding line of the marine-based Antarctic ice sheet may have been further south than Cape Hallett, near the Mariner Glacier (Baroni \& Orombelli 1994). In either case it is likely that the glaciers from the Edisto Inlet would have expanded to cover the present location of Seabee Hook. Seabee Hook has formed during the Holocene as a result of strong currents sweeping material along the coast from the cliff of Cape Hallett and re-depositing it as a series of beach ridges. It is likely that penguins did not occupy the Hook until after it had formed in its entirety. Evidence for this is the even thickness of the layer of "penguin stones" and guano on both current and previously inhabited penguin mounds. Five samples of

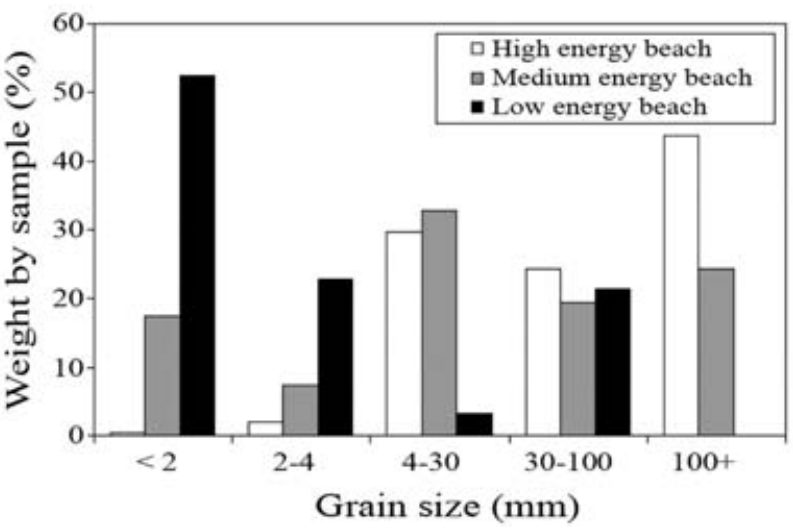

Fig 5. Grain size of material found on high, medium, and low energy beaches at Seabee Hook.

penguin bone and eggshell were radiocarbon dated (Fig. 5).

Late colonization is supported by the presence of the oldest date, (E on Fig. 4), at a relatively shallow depth of 40 $\mathrm{cm}$ on the geologically youngest part of the spit. The radiocarbon dates indicate that Seabee Hook was colonized by penguins at least 1000 years BP (Fig. 4).

\section{Parent material}

The soils mapped at Seabee Hook were all formed from a combination of basaltic sand, gravel and rock materials along with penguin guano and remains. Weathering from the nearby basaltic rock outcrops supplied the material of the Hook. The parent material varies in grain size and roundness. The soils formed near the beaches, and on the main part of Seabee Hook all originated from sub-rounded to rounded beach gravels and coarse sand. Soils formed on, and near, the steep scree slope comprise angular medium to very coarse gravel and boulders.

The materials on the beaches consisted of unconsolidated beach sand, gravel and boulders. The particle size of the gravel and sand on the beaches was influenced by the wave energy reaching each beach (Figs $2 \& 5$ ). Beaches along Willett Cove have sea ice for the majority of the summer, with ice breakout only occurring later in the summer, if at all. The Willet Cove beach is sheltered from waves and it receives considerable guano-rich runoff, which contributes organic material to the upper $2 \mathrm{~cm}$. The lack of high energy waves means the organic matter is not reworked and remains within the beach material, which comprises predominantly sand and silt size particles (Fig. 5). The highest energy beach was that exposed to the Ross Sea on the north-east edge of Seabee Hook, which is subject to high-energy seas during late-summer storms. In the 2004-05 summer, one storm created breaking waves $c .8 \mathrm{~m}$ high. The vigorous wave action provides a steep beach with gravel and coarser materials predominating, including some large ( $>1 \mathrm{~m}$ diameter) boulders. A medium energy beach 


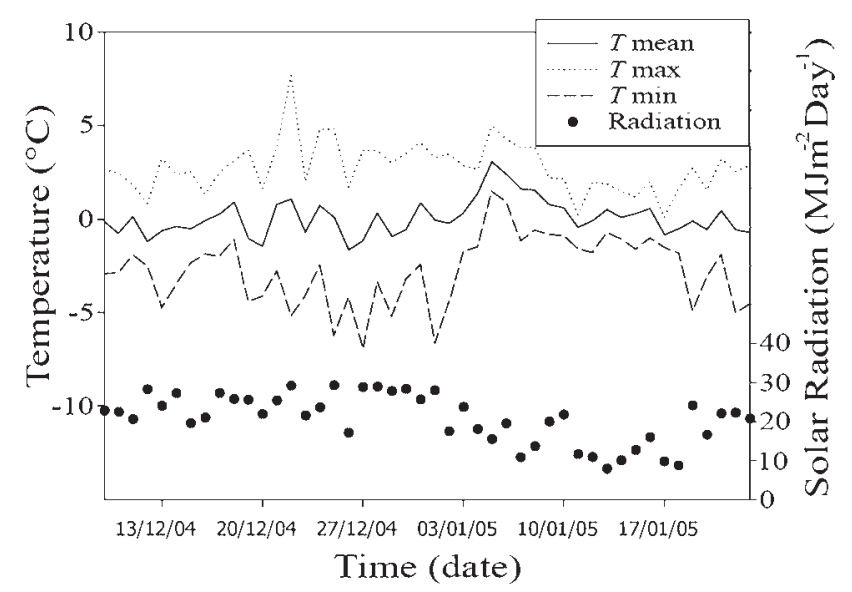

Fig. 6. Daily mean, minimum and maximum air temperature at Seabee Hook from mid December 2004 to late January 2005.

occurs along the coast of Edisto Inlet.

\section{Climate}

The climate at Cape Hallett is relatively mild compared to other regions of continental Antarctica. Data from the climate station located at Seabee Hook over the 2004-05 summer show that the mean air temperature was frequently above $0^{\circ} \mathrm{C}$, and the maximum daily air temperature was above $0^{\circ} \mathrm{C}$ almost every day from mid December 2004 to late January 2005 (Fig. 6). Similar results have been reported from the climate station installed from 1957-64, with January air temperatures frequently above $0^{\circ} \mathrm{C}$ (US Weather Bureau 1963a, 1963b, 1964a, 1964b, 1965a, 1965b). Further climate data for Cape Hallett are available from the Latitudinal Gradient Programme website (www.lpg.aq).

Wind direction at Cape Hallett was predominantly from a SSE to WSW direction during the 2004-05 summer (Fig. 7)

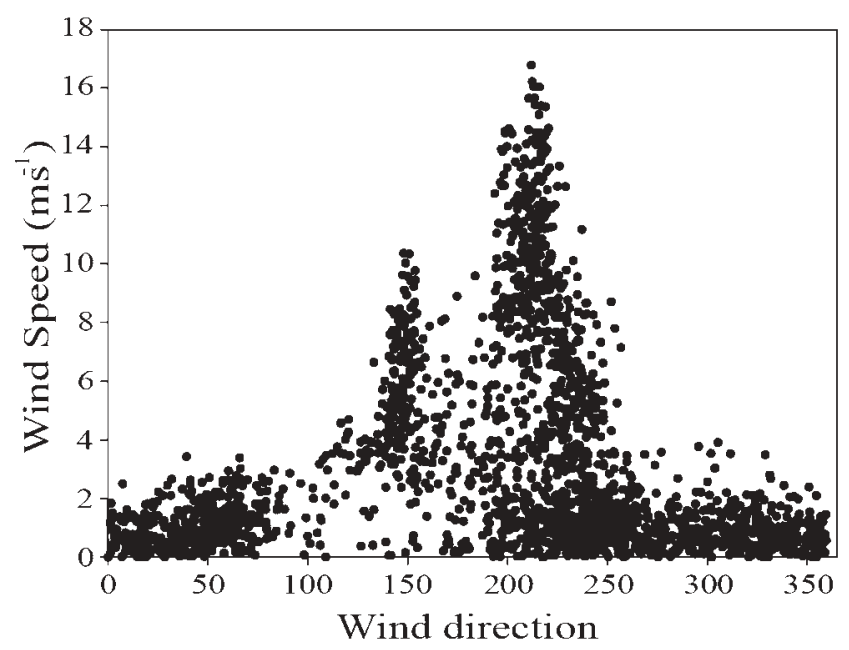

Fig. 7. Wind speed and wind direction at Seabee Hook from mid December 2004 to late January 2005.

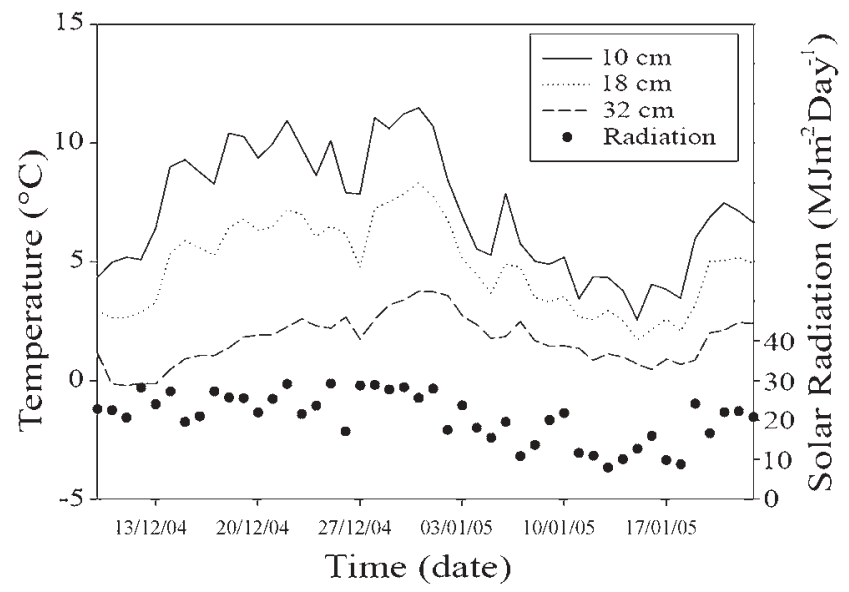

Fig. 8. Daily mean soil temperatures at 10,18 and $32 \mathrm{~cm}$ depth in an intermound soil at Seabee Hook from mid December 2004 to late January 2005.

and also during the summers of 1957-64 (US Weather Bureau 1963a, 1963b, 1964a, 1964b, 1965a, 1965b).

Soil temperatures in January were constantly above $0^{\circ} \mathrm{C}$ at depth (Fig. 8), allowing melt to occur and groundwater to accumulate within a number of soil profiles. Meltwater within soil profiles originated from snow drifts, ice formed within the soil and water that moved down the cliffs and across the south-eastern part of the mapped area. The amount of liquid water at the soil surface was observed to vary from abundant surface water flow observed in January 2003-04 to water largely confined as groundwater in January 2005. January 2006 was observed to be dominated by cloudy conditions (in contrast to January 2005) so there was less diurnal temperature variability near the soil surface than might occur in some summer seasons. The depth to ice cement was greater at Cape Hallett $(\sim 80 \mathrm{~cm})$ than at other locations reported in the McMurdo Sounds region, where permafrost is up to $60 \mathrm{~cm}$ deep (Campbell et al. 1997).

\section{Methods}

Soils were examined by digging pits to the depth of ice cement (c. $80 \mathrm{~cm}$ at maximum thaw in early January). Soil descriptions included here were all made in January 2005 and follow Milne et al. (1995). Soil classification followed USDA soil taxonomy (Soil Survey Staff 2003). A soil map was constructed by landscape interpretation and excavation of soil pits to confirm or refine predictions. Samples were air dried in Antarctica then sealed in plastic bags for transport to a New Zealand laboratory.

Climate data were recorded on the Seabee Hook, from 8 December 2004-24 February 2005, including air temperature (Vaisala Humitter 50Y humidity and temperature sensor), incoming solar radiation (Licor LI200X pyranometer) windspeed (Vector pulse output anemometer A101M), wind direction (Vector potentiometer 


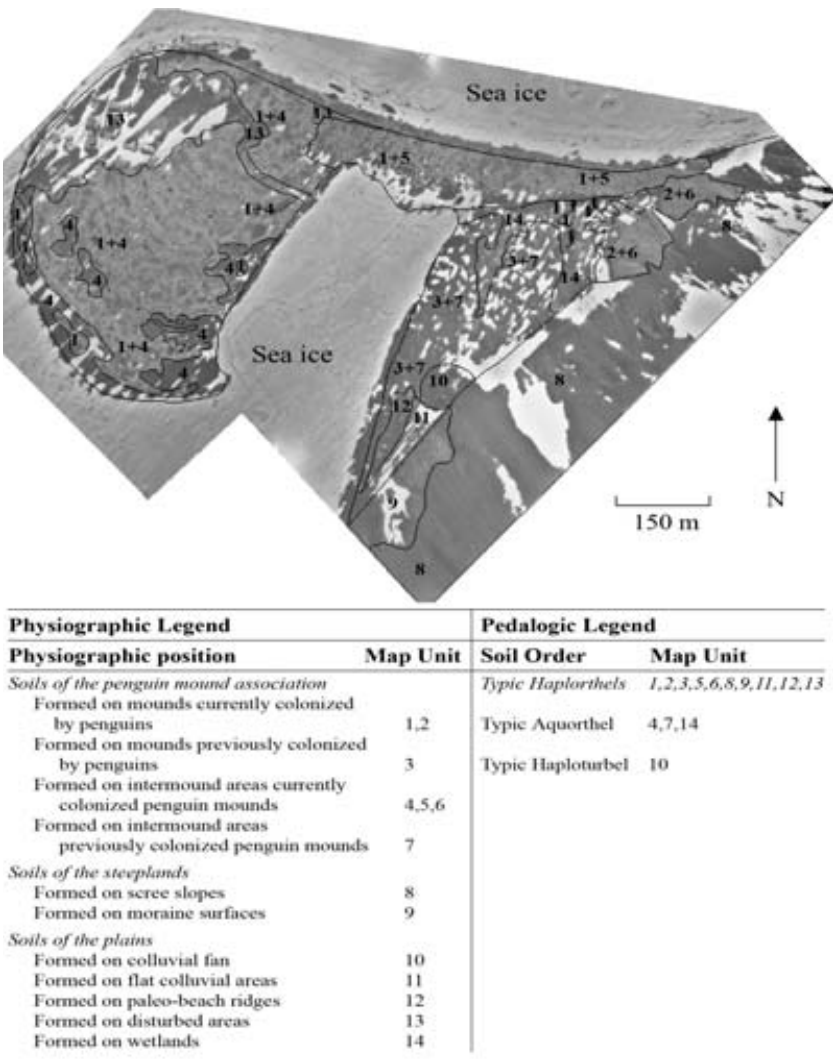

Fig. 9. Soil map of the Seabee Hook area of Cape Hallett (areas with soil associations are marked as $\mathrm{x}+\mathrm{y}$ on the map).

windvane W200P), and soil temperature (Campbell 107 temperature probes). The data were collected using a datalogger (CR10X, Campbell Scientific, Logan, Utah).

Soil $\mathrm{pH}$, and electrical conductivity (EC) were measured following Blakemore et al. (1987) using distilled water as a suspending medium. Soil $\mathrm{pH}$ was measured using an Orion $\mathrm{pH}$ meter and EC was measured using an EDT conductivity probe (model GP383).

Total organic carbon (TOC) was measured using colorimetric determination of organic carbon (Blakemore et al. 1987). Total nitrogen (N) was measured using Kjeldahl digestion (Blakemore et al. 1987). Total element analysis was carried using X-ray fluorescence (XRF) on samples that were ground to a fine powder, and combined with 10-20 drops of PVA-ethanol glue to bind the sample and pressed into a disc at $620 \mathrm{kPa}$ before being dried and analysed. All chemical analyses were carried out in duplicate with the mean results reported. Full datasets are included in Hofstee (2006). In the results and discussion ratings (such as "very low" or "high") for chemical properties follow Blakemore et al. (1987).

Radiocarbon dates were measured at the University of Waikato Radiocarbon Dating Laboratory. Dates were determined using standard radiometric dating techniques and one sample (Wk16685) by Accelerator Mass Spectrometry (AMS). Radiocarbon dates were calibrated a.

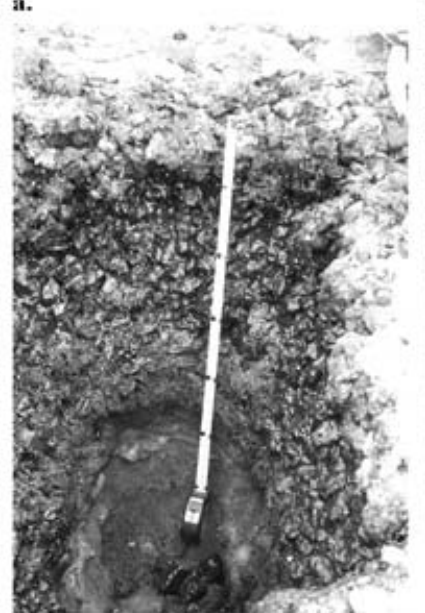

b.
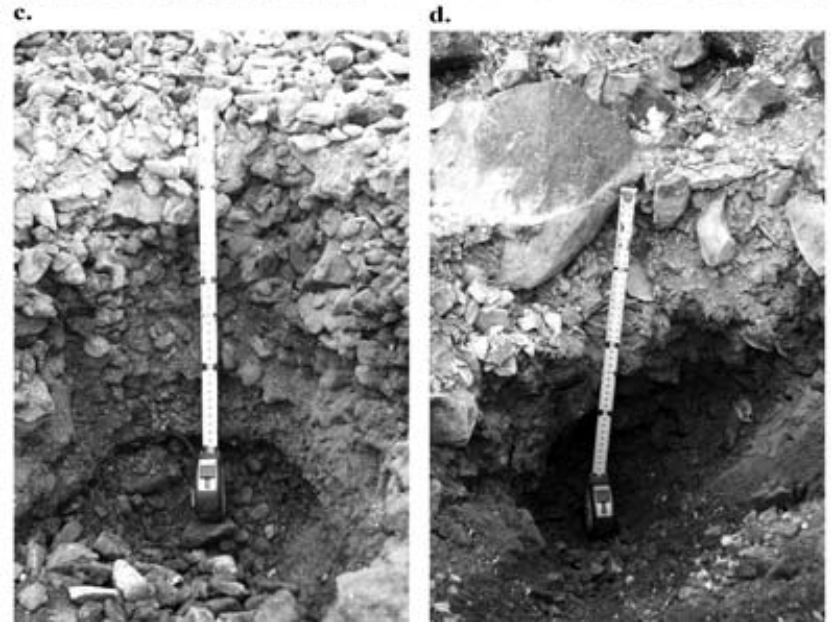

Fig. 10. Soils at Cape Hallett. a. mounds currently colonized by penguins (Unit 1), b. intermound areas of currently colonized penguin mounds (Unit 5), groundwater at $40 \mathrm{~cm}$, c. mounds previously colonized by penguins (Unit 3 ), d. moraine surfaces (Unit 9).

using the marine calibration curve of Hughen et al. (2004), and the program OxCal v3.10 (Bronk-Ramsey 2005), using a reservoir correction of $811 \pm 102$ yrs (Reimer 2005 see http://calib.qub.ac.uk/marine).

\section{Results}

The majority of the soils at Seabee Hook were mapped as soil associations of penguin mound and intermound areas (Figs $9 \& 10$ ) in accordance with the soil landscape model (Fig. 2). Soils not influenced by penguins (nonornithogenic) make up the remainder of the study area and range from wetlands to steep scree slope soils. Soil map unit descriptions are included in Appendix A and further detailed information is included in Hofstee (2006).

\section{Soils of the penguin mound associations}

Ornithogenic soils at Cape Hallett were grouped into four 
soil associations related to the mounds and intermounds, the angularity of gravel materials and the presence or absence of active penguin nests (Fig. 9). Mounds with currently active penguin nests (Soil Map Units 1 and 2, Fig. 10a) had a compacted layer of fresh guano in the upper $2-4 \mathrm{~cm}$. From $4 \mathrm{~cm}$ to about $50 \mathrm{~cm}$ depth "penguin stones" were combined with guano, dead birds, feathers, and eggshells. Beneath the penguin influenced horizons was unweathered beach or fanderived gravels and sands.

Not all penguin mounds at Seabee Hook were colonized every year by breeding penguins. Mounds beneath the steep scree slope (Soil Map Unit 3, Fig. 10c) were not inhabited in the $2003 / 04$ or $2004 / 05$ summers and aerial photos showed no penguin nests in Unit 3 since 1957. However the mounds had been colonized in the past as "penguin stones" and highly decomposed organic matter were present in the top part of the profile.

Within intermound areas (Soil Map Units 4, 5 and 6, Fig. 10b) penguins had removed "penguin stones" from the ground surface to adjacent mounds. Some guano was accumulated in intermound areas, predominantly from water runoff from the mounds and also from direct penguin introduction of guano, dead birds, feathers and eggshells. The amount of runoff and guano in the intermound areas varied in depth from minimal up to a maximum of about $5 \mathrm{~cm}$. Intermound areas in the zone previously inhabited by penguins (Soil Map Unit 7) comprised basalt gravel and sand, and lacked the guano layer found in the intermound areas near active penguin nests.

\section{Soils of the steep lands}

The steep land area comprised the basalt cliffs and slopes of Cape Hallett Peninsula to the east of Seabee Hook (Fig. 2). The slope $\left(\sim 30^{\circ}\right)$, had a number of permanent snow drifts and a small glacier. Skuas nested there during the summer. Ice cement was at a shallower depth $(30-45 \mathrm{~cm}$ in mid January 2005) than on Seabee Hook $(\sim 80 \mathrm{~cm}$ in mid Janurary 2005) probably due to greater shading received on the slope during the night.

The majority of the scree slope (Soil Map Unit 8) consisted of angular basaltic lava and scoria gravels and boulders. The slope stability varied from active fans to slightly more stable slopes, with lichen present on some more stable areas. A moraine (Soil Map Unit 9, Fig. 10d) was situated at the southern end. The moraine was likely to be a lateral moraine from glaciers progressing down Edisto Inlet during the last glaciation. The moraine was composed of locally derived, moderately weathered, angular basalt.

\section{Soils of the plains}

A low angle colluvial fan comprised the lower extension of a large fan situated on the scree slope. The lower section had very little slope $\left(<3^{\circ}\right)$ and was therefore included with the soils of the plain (Soil Map Unit 10). Patterned ground has formed on the surface with some patterns $1 \mathrm{~m}$ in diameter. Other areas of the plain had patterned ground features of around $10 \mathrm{~m}$ diameter.

Within the flat colluvial surface (Soil Map Unit 11) rounded basalt boulders predominated with angular boulders present on the surface, having fallen from the slope above. The series of palaeo-beach ridges at the southeastern edge of Edisto Inlet (Soil Map Unit 12) had a similar geomorphology to the penguin mound and intermound association on Seabee Hook, but were composed of coarser gravels and boulders than those on Seabee Hook. The stones were all subrounded, indicating that they had received wave action, and therefore had not fallen directly from the scree slope.

Activities associated with Hallett Station led to extensive areas of disturbed soil at Seabee Hook (Fig. 9, Soil Map Unit 13). In some areas soil had been disturbed by bulldozing for construction of buildings and roads. Some areas, away from buildings, had been used as rubbish dumps, with soil bulldozed over garbage. Hydrocarbon spills had contaminated soil in some areas, particularly near former fuel tank and drum storage sites. During partial remediation of the site in 1987 a number of artificial penguin mounds were created with a bulldozer to encourage penguin nesting. Penguins had accepted these mounds and had re-created a new layer of "penguin stones" and guano, to a depth of $10 \mathrm{~cm}$ since the construction of the mounds. Beneath the "penguin stones", the bulldozed mounds comprised a mixture of aged guano, beach gravel and sand.

During much of the summer period the wetland area (Soil Map Unit 14) was saturated with meltwater, either in pools or in ephemeral streams. In areas that had no surface water, groundwater was often present within $10 \mathrm{~cm}$ of the soil surface. The wetland area had an abundance of mosses, lichen and algae.

\section{Soil chemical properties}

There were distinct differences in soil $\mathrm{pH}, \mathrm{EC}$ and TOC and $\mathrm{N}$ contents between soils formed on mounds and soils formed without guano influence (Table I). Soils formed on penguin-inhabited mounds had a very high EC, very high total nitrogen and medium to high total organic carbon content. In mound soils, EC decreased to very low values of around $1-2 \mathrm{mS} \mathrm{cm}^{-1}$ at the base of the mounds. The intermound soils had some higher EC values in the upper horizon (up to $3 \mathrm{mS} \mathrm{cm}^{-1}$ ), however the $\mathrm{EC}$ values at the base of intermound soils were similar to $\mathrm{EC}$ values at the base of mound soils. In non-ornithogenic soils EC values were medium to very low $\left(<1 \mathrm{mS} \mathrm{cm}^{-1}\right)$ in the lower horizons (Table I).

Nine samples were analysed using X-Ray Fluorescence (XRF) (Table II). The two upper samples from Unit 1 $(4-15 \mathrm{~cm}$ and $15-25 \mathrm{~cm})$ were from heavily guano 
Table I. Soil chemical data for Cape Hallett soil map units.

\begin{tabular}{|c|c|c|c|c|c|c|c|c|c|c|c|}
\hline & $\begin{array}{l}\text { Depth } \\
\mathrm{cm}\end{array}$ & $\mathrm{pH}$ & $\begin{array}{c}\mathrm{EC} \\
\mathrm{mS} \mathrm{cm}^{-1}\end{array}$ & $\begin{array}{c}\text { Total OC } \\
\%\end{array}$ & $\begin{array}{c}\text { Total N } \\
\%\end{array}$ & & $\begin{array}{l}\text { Depth } \\
\mathrm{cm}\end{array}$ & $\mathrm{pH}$ & $\begin{array}{c}\mathrm{EC} \\
\mathrm{mS} \mathrm{cm}^{-1}\end{array}$ & $\begin{array}{c}\text { Total OC } \\
\%\end{array}$ & $\begin{array}{c}\text { Total N } \\
\%\end{array}$ \\
\hline \multicolumn{6}{|c|}{ Soils of the penguin mounds } & \multicolumn{6}{|c|}{ Soils of the steep lands } \\
\hline \multicolumn{6}{|c|}{ Formed on mounds currently colonized by penguins } & \multicolumn{6}{|c|}{ Formed on scree slopes } \\
\hline \multirow[t]{6}{*}{ Unit 1} & $0-4$ & - & - & 17.6 & 8.88 & Unit 8 & $0-10+$ & - & - & 5.3 & 1.21 \\
\hline & $4-15$ & 7.5 & 27.40 & 16.8 & 1.90 & \multicolumn{6}{|c|}{ Formed on moraine surfaces } \\
\hline & $15-25$ & 7.0 & 13.36 & 11.0 & 1.81 & \multirow[t]{3}{*}{ Unit 9} & $0-2$ & 6.9 & 1.75 & 1.7 & 0.97 \\
\hline & $25-55$ & 7.3 & 5.21 & 3.2 & 1.59 & & $2-20$ & 4.7 & 0.55 & 1.0 & 0.55 \\
\hline & $55-70+$ & 7.8 & 0.97 & 3.0 & 0.66 & & $20-45+$ & 3.8 & 0.22 & 0.53 & 0.17 \\
\hline & & & & & & \multicolumn{6}{|c|}{ Soils of the plains } \\
\hline \multirow{8}{*}{ Unit 1} & $0-4$ & 5.8 & 23.5 & 9.9 & 12.07 & \multicolumn{6}{|c|}{ Formed on colluvial fan } \\
\hline & $4-20$ & 6.6 & 43.00 & 10.0 & 4.09 & \multirow[t]{3}{*}{ Unit 10} & $0-2$ & 6.1 & 0.34 & 0.89 & 0.23 \\
\hline & $20-60$ & 6.2 & 32.6 & 11.4 & 3.76 & & $2-35$ & 6.1 & 0.13 & 1.5 & 0.25 \\
\hline & $60-70$ & 7.6 & 2.72 & 5.5 & 2.40 & & $35-40+$ & 6.4 & 0.04 & 0.00 & 0.10 \\
\hline & $70-80$ & 8.1 & 1.41 & 7.2 & 2.69 & \multicolumn{6}{|c|}{ Formed on flat colluvial areas } \\
\hline & $80-90$ & 8.3 & 0.56 & 0.17 & 0.60 & \multirow[t]{3}{*}{ Unit 11} & $0-2$ & 6.3 & 0.04 & 0.75 & 0.07 \\
\hline & $90-95+$ & 7.4 & 2.26 & 5.9 & 2.99 & & $2-10$ & 6.8 & 0.02 & 1.0 & 0.05 \\
\hline & & & & & & & $10-50+$ & 7.2 & 0.01 & 0.68 & 0.05 \\
\hline \multirow[t]{5}{*}{ Unit 2} & $0-2$ & - & 22.80 & 11.2 & 14.53 & \multicolumn{6}{|c|}{ Formed on paleo beach ridges } \\
\hline & $2-10$ & - & - & 9.2 & 4.65 & \multirow[t]{3}{*}{ Unit 12} & $0-2$ & 6.0 & 0.39 & 0.62 & 0.14 \\
\hline & $10-20$ & - & - & 11.5 & 4.17 & & $2-25+$ & 5.3 & 0.12 & 0.21 & 0.00 \\
\hline & $20-40$ & 6.3 & 25.10 & 6.4 & 4.02 & & & & & & \\
\hline & $40-50+$ & - & - & 7.9 & 2.78 & Unit 12 & $0-2$ & 6.7 & 0.47 & 3.2 & 0.28 \\
\hline \multicolumn{6}{|c|}{ Formed on mounds previously colonized by penguins } & & $2-10$ & 5.3 & 0.28 & 0.89 & 0.18 \\
\hline \multirow[t]{6}{*}{ Unit 3} & $0-2$ & - & - & 8.4 & 2.31 & & $10-25$ & 4.0 & 0.17 & 0.60 & 0.08 \\
\hline & $2-25$ & 6.7 & 18.20 & 6.6 & 4.04 & & $25-65+$ & 5.5 & 0.08 & 0.11 & 0.03 \\
\hline & $25-35$ & 6.9 & 11.31 & 3.6 & 2.62 & Formed & urbed are & & & & \\
\hline & $35-55$ & 7.1 & - & 4.1 & 2.09 & Unit 13 & $0-4$ & 6.9 & 32.80 & 8.7 & 10.14 \\
\hline & $55-80$ & - & - & 2.6 & 0.92 & & $4-10$ & 6.8 & 8.52 & 6.0 & 3.54 \\
\hline & $80-100+$ & 7.5 & 1.24 & 1.1 & 0.66 & & $10-30+$ & 7.1 & 1.97 & 3.0 & 1.85 \\
\hline \multicolumn{6}{|c|}{ Formed on intermound areas of currently colonized penguin mounds } & \multicolumn{6}{|c|}{ Formed on wetlands } \\
\hline Unit 4 & $0-2$ & 7.9 & 2.01 & 13.0 & 2.45 & Unit 14 & $0-2$ & 4.7 & 0.29 & 2.4 & 0.36 \\
\hline & $2-4$ & 6.7 & 0.41 & 6.4 & 0.65 & & $0-2$ & 5.4 & 0.09 & 7.0 & 0.80 \\
\hline & $4-63+$ & 6.9 & 0.67 & 3.8 & 0.53 & & $0-2$ & 6.4 & 0.10 & 11.2 & 0.95 \\
\hline & & & & & & & $0--2$ & 6.3 & 0.03 & 2.7 & 0.31 \\
\hline Unit 5 & $0-4$ & 7.2 & 2.87 & 6.8 & 2.86 & & & & & & \\
\hline & $4-10$ & 6.4 & 0.56 & 1.6 & 0.43 & & $0-2$ & 6.9 & 0.17 & 1.3 & 0.38 \\
\hline & $10-30$ & 6.4 & 1.04 & 5.1 & 1.38 & & $0-2$ & 6.8 & 0.29 & 2.9 & 0.46 \\
\hline & $30-50$ & 7.2 & 1.20 & 1.9 & 3.01 & & $0-2$ & - & - & 10.4 & 1.81 \\
\hline & $50-60+$ & 7.0 & 1.83 & 0.94 & 3.05 & & $0-2$ & - & - & 5.6 & 0.71 \\
\hline & & & & & & Material & beaches: & & & & \\
\hline Unit 6 & $0-5$ & 6.4 & 0.97 & 2.2 & 0.44 & Materia & h energy & & & & \\
\hline & $5-30$ & 4.4 & 1.23 & 6.9 & 0.79 & & $0-10+$ & 6.4 & 0.35 & 0.00 & 0.03 \\
\hline & $30-60+$ & 5.8 & 0.59 & 7.0 & 1.01 & Material & $\mathrm{N}$ energy $\mathrm{b}$ & & & & \\
\hline Formed & termound & $\mathrm{s}$ of pr & isly coloni & penguin $n$ & nds & & $0-2$ & 7.2 & 2.06 & 42.4 & 0.66 \\
\hline Unit 7 & $0-2$ & 5.1 & 0.45 & 5.0 & 0.87 & & $2-20+$ & 7.2 & 0.96 & 2.7 & 0.29 \\
\hline & $2-5$ & 4.9 & 0.25 & 4.9 & 0.94 & & & & & & \\
\hline & $5-40+$ & 4.4 & 0.08 & 0.39 & 0.16 & & & & & & \\
\hline
\end{tabular}

impacted soil, and are effectively an analysis of the guano. The sample from the base of a Unit 1 soil profile was taken from within the subrounded basalt gravel and sand, common to all profiles on the hook.

\section{Discussion}

As all the soils at Seabee Hook have permafrost within one metre of the soil surface they are classified as Gelisols as defined by Soil Survey Staff (2003). Soils with organic matter introduced by penguins were classified as Typic
Haplorthels. At Cape Hallett the soil organic carbon content was below the $20 \%$ threshold required to classify soils as Histels, with much of the guano material present as phosphorus (12\%), rather than organic carbon. Soils on abandoned penguin colonies have previously been classified as Lithic Haplorthels (Beyer et al. 1999). However, at Seabee Hook the abandoned colonies have been classified separately as mounds (Typic Haplorthels) and intermounds (Typic Aquorthels). Soils in the intergrade area between the mounds and intermounds, though not described in detail here, would be classified as Aquic 
Table II. Results from XRF analysis (a dash indicates composition less than detection limit).

\begin{tabular}{|c|c|c|c|c|c|c|c|c|c|}
\hline $\begin{array}{l}\text { Element a } \\
\text { ppm }\end{array}$ & $\begin{array}{l}\text { dimension } \\
\text { Unit } 1 \\
4-15 \mathrm{~cm}\end{array}$ & $\begin{array}{c}\text { Unit } 1 \\
15-25 \mathrm{~cm}\end{array}$ & $\begin{array}{c}\text { Unit } 1 \\
55-70 \mathrm{~cm}\end{array}$ & $\begin{array}{l}\text { Unit } 4 \\
2-4 \mathrm{~cm}\end{array}$ & $\begin{array}{c}\text { Unit } 4 \\
4-63 \mathrm{~cm}\end{array}$ & $\begin{array}{c}\text { Beach } \\
0-20 \mathrm{~cm}\end{array}$ & $\begin{array}{l}\text { Unit } 9 \\
0-2 \mathrm{~cm}\end{array}$ & $\begin{array}{c}\text { Unit } 9 \\
2-20 \mathrm{~cm}\end{array}$ & $\begin{array}{c}\text { Unit } 9 \\
20-45 \mathrm{~cm}\end{array}$ \\
\hline $\mathrm{Na} \%$ & 3 & 2 & 4 & 4 & 5 & 5 & 4 & 4 & 4 \\
\hline $\mathrm{Mg} \%$ & 4 & 6 & 3 & 2 & 2 & 3 & 2 & 1 & 2 \\
\hline $\mathrm{Al} \%$ & 0 & 1 & 9 & 9 & 9 & 9 & 9 & 10 & 9 \\
\hline $\mathrm{Si} \%$ & 2 & 3 & 23 & 23 & 24 & 24 & 24 & 24 & 25 \\
\hline $\mathrm{P} \%$ & 9.8 & 12.3 & 1.1 & 0.8 & 0.7 & 0.4 & 1.4 & 1.4 & 1.2 \\
\hline $\mathrm{K} \%$ & 0.7 & 0.8 & 1.9 & 1.9 & 2.0 & 1.9 & 1.8 & 1.8 & 1.8 \\
\hline $\mathrm{Ca} \%$ & 9 & 12 & 6 & 6 & 6 & 6 & 6 & 5 & 5 \\
\hline $\mathrm{Ti} \%$ & 0.0 & 0.1 & 1.4 & 1.4 & 1.4 & 1.4 & 1.4 & 1.4 & 1.4 \\
\hline $\mathrm{V} \mu \mathrm{g} \mathrm{g}^{-1}$ & 4 & 11 & 180 & 180 & 170 & 160 & 150 & 150 & 160 \\
\hline $\mathrm{Cr} \mu \mathrm{g} \mathrm{g}^{-1}$ & 4 & 11 & 140 & 110 & 95 & 210 & 36 & 27 & 35 \\
\hline $\mathrm{Mn} \%$ & 0.0 & 0.0 & 0.2 & 0.2 & 0.2 & 0.2 & 0.2 & 0.2 & 0.2 \\
\hline $\mathrm{Zn} \mu \mathrm{g} \mathrm{g}^{-1}$ & 520 & 580 & 130 & 130 & 120 & 120 & 140 & 130 & 130 \\
\hline $\mathrm{Ga} \mu \mathrm{g} \mathrm{g}^{-1}$ & 1 & 2 & 22 & 23 & 22 & 22 & 23 & 23 & 25 \\
\hline As $\mu \mathrm{g} \mathrm{g}^{-1}$ & 13 & 10 & - & 1 & 2 & 0 & 4 & 5 & 6 \\
\hline Se $\mu \mathrm{g} \mathrm{g}^{-1}$ & 43 & 41 & 1 & 1 & 1 & - & 1 & 1 & 1 \\
\hline $\mathrm{Br} \mu \mathrm{g} \mathrm{g}^{-1}$ & 431 & 433 & 9 & 5 & 5 & 5 & 8 & 6 & 6 \\
\hline $\mathrm{Rb} \mu \mathrm{g} \mathrm{g}^{-1}$ & 8 & 12 & 56 & 57 & 57 & 54 & 52 & 55 & 54 \\
\hline $\mathrm{Sr} \mu \mathrm{g} \mathrm{g}^{-1}$ & 1440 & 1600 & 970 & 970 & 960 & 890 & 1050 & 1040 & 1090 \\
\hline $\mathrm{Y} \mu \mathrm{g} \mathrm{g}^{-1}$ & 2 & 5 & 34 & 35 & 35 & 33 & 34 & 34 & 35 \\
\hline $\mathrm{Zr} \mu \mathrm{g} \mathrm{g}^{-1}$ & 18 & 48 & 390 & 400 & 404 & 378 & 401 & 410 & 433 \\
\hline $\mathrm{Nb} \mu \mathrm{g} \mathrm{g}^{-1}$ & 7 & 16 & 122 & 126 & 126 & 124 & 132 & 134 & 143 \\
\hline Mo $\mu \mathrm{g} \mathrm{g}^{-1}$ & 1 & 2 & 5 & 6 & 6 & 5 & 5 & 5 & 6 \\
\hline $\mathrm{Ag} \mu \mathrm{g} \mathrm{g}^{-1}$ & 13 & 13 & - & - & - & - & - & - & - \\
\hline
\end{tabular}

Haplorthels because of their high water table. Soils formed away from penguin mound associations at Seabee Hook were classified as Typic Haplothels, and one soil (Unit 10) that was formed on patterned ground was classified as a Typic Haploturbel. All the soils at Cape Hallett were classified at the family level as fragmental, mixed, hypergelic.

The soil EC was higher in soils formed from guano (generally about $\left.15 \mathrm{mS} \mathrm{cm}^{-1}\right)$ than in mineral soils $(<1 \mathrm{mS}$ $\mathrm{cm}^{-1}$, Table I). Mound soil ECs were similar to those reported at Cape Royds (18 mS cm${ }^{-1}$, Ugolini 1972). The organic carbon values were high (up to $18 \%$ ) in the upper horizon of mound soils, and decreased in the lower horizons (to $1 \%$ ) (Table I). Higher organic carbon contents (up to $30 \%$ ) have been reported for other Antarctic ornithogenic soils (e.g. Tatur 1989) with levels of $22 \%$ reported at Cape Royds (Ugolini 1972) and 24\% at Cape Bird (Speir \& Cowling 1984). The organic carbon in the intermound soil varied considerably, but was higher near the surface than at the base of the profile (Table I).

Nitrogen originates from the high protein diet of the penguins (Ugolini 1972). Total nitrogen contents of up to $17 \%$ were recorded in the upper horizons of the mound soil
(Table I) that was similar to other locations around the Ross Sea region (14-16\%), but considerably higher than total nitrogen reported in ornithogenic soils at King George Island (4\%) (Tatur \& Mycrcha 1984). Nitrogen levels decreased through the soil profile to around $1 \%$ at the base. Soil profiles away from penguin influence had low nitrogen values, usually below $1 \%$ (Table I). The very low carbon:nitrogen ratio, (approximately 2), was similar to that reported in fresh guano deposits (Zdanowski et al. 2005). The majority of the total nitrogen is likely to be primarily in the form of ammonia (Ugolini 1972, Speir \& Cowling 1984). Some loss of ammonia may have occurred during transport of samples to New Zealand, so the values reported here could be regarded as minimum values. Speir \& Cowling (1984) reported that the uric acid content of ornithogenic soils was high $(<9 \%)$ at Cape Bird.

The samples from Units 4, 9 and 12 and the 55-70 cm sample from Unit 1 have signatures common to alkali basalts (R.M. Briggs, personal communication 2005) as would be expected as the samples originate either from the basaltic beach or scree materials. The abundance of sodium and chlorine in all samples was likely to have been the result of proximity to the ocean. 
Phosphorus, sulphur, magnesium, calcium, arsenic, copper, zinc and cadmium were all concentrated within the guano rich Unit 1 samples compared to the basalt rich samples. Similarly high concentrations in fresh penguin guano have been previously reported (Ancora et al. 2002, Zdanowski et al. 2005).

The concentration of phosphorus within the basalt was about $1 \%$, whereas phosphorus content of up to $12 \%$ occurred within the guano rich samples (Table I). The surface phosphorus concentrations compare to some maritime Antarctic soils where surface phosphorus concentrations of about $12 \%$ were reported at Anvers Island, Cormorant Island, and Seymour Island, all near the Antarctic Peninsula (Tatur 1989), while total P concentrations of (14\%) were reported for soil materials from King George Island (Tatur \& Myrcha 1984, Tatur 1989). Lower phosphorus concentrations (5-6\%) have been reported for other areas of the Ross Sea (Ugolini 1972, Speir \& Cowling 1984).

Cadmium levels were high in guano-derived material (14-16 $\left.\mu \mathrm{g} \mathrm{g}^{-1}\right)$ and below the detectable limit in non-guano soils. Cadmium within guano originates from high cadmium levels in upwelling Antarctic water that is ingested through the food chain by Adélie penguins (Ancora et al. 2002). Cadmium in fresh penguin guano was reported to be around $5.5 \mu \mathrm{g} \mathrm{g}^{-1}$ by Ancora et al. (2002), which was lower than the cadmium found in the ornithogenic soil at Cape Hallett.

The zinc content was higher in guano rich soils than the basalt derived soil materials, with concentrations of around $500 \mu \mathrm{g} \mathrm{g}^{-1}$. The zinc concentrations in guano at Cape Hallett were comparable to zinc concentrations in decomposed guano at King George Island (646 $\left.\mu \mathrm{g} \mathrm{g}^{-1}\right)$ in the maritime Antarctic (Zdanowski et al. 2005).

Copper content of around $400 \mu \mathrm{g} \mathrm{g}^{-1}$ was reported in surface soils of King George Island, Anvers Island, Cormorant Island, and Seymour Island (Tatur 1989) and are comparable to the elevated copper found in surface soils of Cape Hallett.

Radiocarbon dates obtained for inhabited colonies around the Ross Sea region give dates much older than the dates from Cape Hallett (Speir \& Cowling 1984, Heine \& Spier 1989, Baroni \& Orombelli 1991, 1994). Seabee Hook may have been inhabited by penguins later than other areas of the Ross Sea due to the building of Seabee Hook occurring only in the Holocene.

\section{Conclusions}

This paper reports on, and maps, the soil-landscape relationship for soils in the Seabee Hook area of Cape Hallett, Antarctica. The ornithogenic soils at Seabee Hook had high organic matter content, high electrical conductivity, and high concentrations of nitrogen, phosphorus, cadmium, zinc and copper, all due to additions of penguin guano, dead birds, feathers and eggshells. The mineral soils comprised gravel and sand, dominated by weakly weathered basalts. The soil-landscape model (Fig. 3) is likely to be applicable to other Adélie penguin colonies on the Antarctic coast and could be tested at other sites of penguin habitation.

Seabee Hook has warmer summer temperatures and higher precipitation than many areas further south within the LGP region, allowing an extensive, thin, unconfined aquifer to develop above the ice cement during the summer (Hofstee et al. 2006). Compared to other locations in the Ross Sea Region, relatively active soil development occurs as a result of higher temperature and moisture as well as ornithogenic inputs. However, a relatively short time for soil formation limits the extent and development of weathering processes. The Seabee Hook spit comprises a series of beach ridges formed during the Holocene which thus constrains the maximum age of soils on the spit to less than 10000 years. Radiocarbon dating indicates that penguins have been present on the entire spit area for at least 1000 years. Current penguin activity means that the ornithogenic soils are still actively up-building and developing. The soils on the lateral moraine at the foot of the steep slopes of the Cape Hallett Peninsula are older than 10000 years, dating to at least the last glaciation and possibly to earlier glacial events.

\section{Acknowledgements}

This research was supported by The New Zealand foundation for Research Science and Technology, (FRST grant C09X0307) and logistical support and additional funding was provided by Antarctica New Zealand including the Antarctica New Zealand LGP postgraduate scholarship. Gus McAllister and Rachel Brown assisted in the field, Roger Briggs provided XRF expertise, Tarnia Hodges provided laboratory assistance and Malcolm McLeod gave helpful comments on the draft. Catherine Beard identified the predominant moss species. We thank the reviewers for their helpful comments.

\section{References}

Ancora, S., Volpi, V., Olmastroni, S., Focardi, S. \& Leonzio, C. 2002. Assumption and elimination of trace elements in Adélie penguins from Antarctica: a preliminary study. Marine Environmental Research, 54, 341-344.

Baroni, C. \& Orombelli, G. 1991. Holocene raised beaches at Terra Nova Bay, Victoria Land, Antarctica. Quaternary Research, 36,157-177.

Baroni, C. \& Orombelli, G. 1994. Abandoned penguin rookeries as Holocene paleoclimatic indicators in Antarctica. Geology, 22, 23-26.

Benes, N.S. 1960. Soil temperatures at Cape Hallett, Antarctica, 1958. Monthly Weather Review, June, 223-227.

Beyer, L., Bockheim, J.G., Campbell, I.B. \& Claridge, G.G.C. 1999. Review. Genesis, properties and sensitivity of Antarctic Gelisols. Antarctic Science, 11, 387-398. 
Blakemore, L.C., Searle, P.L. \& Daly, B.K. 1987. Methods for chemical analysis of soils. NZ Soil Bureau Scientific Report, No. 80, 103 pp.

Brabyn, L., Green, A., Beard, C. \& Seppelt, R. 2005. GiS goes nano: vegetation studies in Victoria Land, Antarctica. New Zealand Geographer, 61, 139-147.

Bronk-RAmSEY, C. 2005. OxCal program v3.10. Oxford Radiocarbon Accelerator Unit.

Campbell, I.B. \& Claridge, G.G.C. 1966. A sequence of soils from a penguin rookery, Inexpressible Island, Antarctica. New Zealand Journal of Science, 9, 361-372.

Campbell, I.B. \& Claridge, G.G.C. 1968. Soils in the vicinity of Edisto Inlet, Victoria Land, Antarctica. New Zealand Journal of Science, 11, 498-520.

Campbell, I.B., Claridge, G.G.C., Balks, M.R., Campbell, D.I. 1997. Moisture content in soils of the McMurdo Sound and Dry Valley region of Antarctica. In Lyons, W.B., Howard-Williams, C. \& Hawes, I., eds. Ecosystem processes in Antarctic ice-free landscapes. Rotterdam: Balkema, 61-76.

Claridge, G.G.C. 1965. The clay mineralogy and chemistry of some soils from the Ross Dependency, Antarctica. New Zealand Journal of Geology and Geophysics, 8, 186-220.

Hall, B.L., Baroni, C. \& Denton, G.H. 2004. Holocene relative sea-level history of the southern Victoria Land Coast, Antarctica. Global and Planetary Change, 42, 241-263.

HaRrington, H.J. \& MCKellar, I.C. 1958. A radiocarbon date for penguin colonization of Cape Hallett, Antarctica. NZ Journal of Geology and Geophysics, 1, 571-576.

Harrington, H.J., Wood, B.L., McKellar, I.C. \& Lensen, G.J. 1967. Topography and geology of the Cape Hallett district, Victoria Land, Antarctica. New Zealand Geological Survey Bulletin, No. 80, 100 pp.

Heine, J.C. \& Speir, T.W. 1989. Ornithogenic soils of the Cape Bird Adélie penguin rookeries, Antarctica. Polar Biology, 10, 89-99.

HofsteE, E. 2006. Soil mapping and groundwater characterization at Cape Hallett, Antarctica. MSc thesis, Department of Earth Science, University of Waikato, New Zealand. [Unpublished]

Hofstee, E.H., Campbell, D.I., Balks, M.R. \& Aislabie, J. 2006. Groundwater characteristics at Seabee Hook, Cape Hallett, Antarctica. Antarctic Science, 18, 487-495.

Howard-Williams, C., Peterson, D., Lyons, W.B., Cattaneo-Vietti, R. \& GoRDON, S. 2006. Measuring ecosystem response in a rapidly changing environment: the Latitudinal Gradient Project. Antarctic Science, 18, 465-471.

Hughen, K.A, Baillie, M.G.L., Bard, E., Beck, J.W., Bertrand, C.J.H., Blackwell, P.G., Buck, C.E., Burr, G.S., Cutler, K.B., Damon, P.E., Edwards, R.L., Fairbanks, R.G., Friedrich, M., Guilderson, T.P., Kromer, B., McCormac, G., Manning, S., Bronk-Ramsey, C., Reimer, P.J., Reimer, R.W., Remmele, S., Southon, J.R., Stuiver, M., Talamo, S., Taylor, F.W., van der Plicht, J. \& Weyhenmeyer, C.E. 2004. Marine04 Marine Radiocarbon Age Calibration, 0-26 Cal Kyr BP. Radiocarbon, 46, 1059-1086.

Juchnowicz-Bierbasz, M. \& Rakusa-SuszcZewski, S. 2002. Nutrients and cations content in soil solutions from the present and abandoned penguin rookeries (Antarctica, King George Island). Polish Journal of Ecology, 50, 79-91.

MCCRAW, J.D. 1967. Soils of the Taylor Dry Valley, Victoria Land, Antarctica, with notes on soils from other localities in Victoria Land. New Zealand Journal of Geology and Geophysics, 10, 498-539.

Milne, J.D.G., Claydon, B., Singleton, P.L. \& Wilson, A.D. 1995. Soil description handbook. Revised ed. Lincoln, NZ: Manaaki Whenua Press, $157 \mathrm{pp}$.

Myrcha, A. \& TAtur, A. 1991. Ecological role of the current and abandoned penguin rookeries in the land environment of the maritime Antarctic. Polish Polar Research, 12, 3-24.
Myrcha, A., Pietr, S.J. \& Tatur, A. 1985. The role of Pygoscelid penguin rookeries in nutrient cycles at Admiralty Bay, King George Island. In Siegfried, W.R., Condy, P.R. \& Laws, R.M., eds. Antarctic nutrient cycles and food webs. Berlin: Springer, 156-162.

ORCHARD, V.A. \& CORDEROY, D.M. 1983. Influence of environmental factors on the decomposition of penguin guano in Antarctica. Polar Biology, 1, 199-204.

Pietr, S.J., Tatur, A. \& Myrcha, A. 1983. Mineralisation of penguin excrements in the Admiralty Bay region (King George Island, South Shetland Islands, Antarctica). Polish Polar Research, 4, 97-112.

PorazinSKA, D.L., WAll, D.H. \& Virginia, R.A. 2002. Invertebrates in ornithogenic soils on Ross Island, Antarctica. Polar Biology, 25, 569-574.

RAMSAY, A.J. 1983. Bacterial biomass in Ornithogenic soils of Antarctica. Polar Biology, 1, 221-225.

RAMSAY, A.J. \& STANNARD, R.E. 1986. Numbers and viability of bacteria in ornithogenic soils of Antarctica. Polar Biology, 5, 195-198.

Roser, D.J., Seppelt, R.D. \& Ashbolt, N. 1993. Microbiology of ornithogenic soils from the Windmill Islands, Budd Coast, continental Antarctica: microbial biomass distribution. Soil Biology and Biochemistry, 25, 165-175.

RuDOLPH, E.D. 1963. Vegetation of Hallett Station area, Victoria Land, Antarctica. Ecology, 44, 585-586.

Soll Survey Staff. 2003. Keys to soil taxonomy, 9th ed. Washington, DC: USDA-NRCC $332 \mathrm{pp}$.

SPeIR, T.W. \& Cowling, J.C. 1984. Ornithogenic soils of the Cape Bird Adélie penguin rookeries, Antarctica. 1. Chemical properties. Polar Biology, 2, 199-205.

SpeIR, T.W. \& Ross, D.J. 1984. Ornithogenic soils of the Cape Bird Adélie penguin rookeries, Antarctica. 2. Ammonia evolution and enzyme activities. Polar Biology, 2, 207-212.

SYROECHKOVSKY, E.E. 1959. The role of animals in primary soil formation under the conditions of pre-polar regions of the globe (exemplified by the Antarctic). Zoologichesky Zhurnal, 38, 1770-1775.

TAtur, A. 1989. Ornithogenic soils of the maritime Antarctic. Polish Polar Research, 10, 481-532.

Tatur, A. \& Myrcha, A. 1983. Changes in chemical composition of waters running off from the penguin rookeries in the Admiralty Bay region (King George Island, South Shetland Islands, Antarctica). Polish Polar Research, 4, 113-125.

TAtur, A. \& MYrcha, A. 1984. Ornithogenic soils on King George Island, South Shetland Islands (Maritime Antarctic Zone). Polish Polar Research, 5, 31-60.

TAtur, A. \& BARCZUK, A. 1985. Ornithogenic phosphates on King George Island in the Maritime Antarctic. In Siegfried, W.R., Condy, P.R. \& Laws, R.M., eds. Antarctic nutrient cycles and food webs. Berlin: Springer, 163-168.

Tatur, A., Myrcha, A. \& Niegodzisz, J. 1997. Formation of abandoned penguin rookery ecosystems in the maritime Antarctic. Polar Biology, 17, 405-417.

Tscherko, D., Bolter, M., Beyer, L., Chen, J., Elster, J., Kandeler, E., Kunn, D. \& Blume, H.-P. 2003. Biomass and enzyme activity of two soil transects at King George Island, Maritime Antarctica. Arctic, Antarctic and Alpine Research, 35, 34-47.

UgOLINI, F.C. 1972. Ornithogenic soils of Antarctica. Antarctic Research Series, 20, 181-193.

US Weather Bureau. 1963a. Climatological data for Antarctic stations, All data thru June 1957, and January-December 1959. No. 2. Washington, DC: U.S. Department of Commerce.

US Weather Bureau. 1963b. Climatological data for Antarctic stations, January-December 1960. No. 3. Washington DC: US Department of Commerce.

US Weather Bureau. 1964a. Climatological data for Antarctic stations, January-December 1961. No. 4. Washington DC: US Department of Commerce. 
US Weather Bureau. 1964b. Climatological data for Antarctic stations, January-December 1962. No. 5. Washington DC: US Department of Commerce.

US Weather Bureau. 1965a. Climatological data for Antarctic stations, January-December 1963. No. 6. Washington DC: US Department of Commerce.
US Weather Bureau. 1965b. Climatological data for Antarctic stations, January-December 1964. No. 7. Washington DC: US Department of Commerce.

ZDANOWSKI, M.K., ZMUNDA, M.J. \& ZwolsKa, I. 2005. Bacterical role in the decomposition of marine-derived material (penguin guano) in the terrestrial maritime Antarctic. Soil Biology \& Biochemistry, 37, $581-595$. 


\section{Appendix A. Soil map unit descriptions}

\section{Soil Map Unit 1}

The mounds within Unit 1 were on beach ridges (Fig. 9 \& Fig. 10a) and were characterized by "penguin stones" of rounded basalt gravel to a depth of about $50 \mathrm{~cm}$. The surface of the mounds varied in colour during the summer as the penguin's diet changed and therefore so did the colour of the guano deposited on the soil surface. In January 2005 the ice cement was at $80 \mathrm{~cm}$ depth.

\section{Typical profile description}

\section{Depth $(\mathrm{cm}) \quad$ Description}

0-4 Dull orange (7.5YR 7/3) to light grey (7.5YR $8 / 2$ ) dense guano, smooth distinct boundary,

4-20 Brownish black (7.5YR 2/2) to very dark reddish brown (5YR 2/4) extremely gravelly guano, sub-rounded coarse to very coarse basalt gravel "penguin stones", very sticky, wavy indistinct boundary,

20-30 Dark reddish brown (5YR 3/2), extremely gravelly guano, sub-rounded coarse to very coarse basalt gravel "penguin stones", very sticky, wavy indistinct boundary,

30-50 Brown (10YR 4/6) extremely gravelly guano, sub-rounded coarse to very coarse basalt "penguin stones", rounded basalt boulders, moderately sticky, wavy abrupt boundary,

50-80+ Reddish black (10R 1.7/1) to black (5YR 1.7/1) moderately gravelly coarse sand, sub-rounded coarse basalt gravel, rounded basalt boulders.

\section{Soil Map Unit 2}

The mounds on the fan (Fig. 9) were of "penguin stones" of locally derived angular scree. The penguin mound soils in the upper sections of the fan had a shallower penguin stone layer presumably because the higher areas are not colonized every year, or have only recently started being colonized. In January 2005 ice cement was at $50 \mathrm{~cm}$.

\section{Typical profile description}

Depth $(\mathrm{cm}) \quad$ Description

0-2 Reddish brown (10R 5/4) to pale reddish brown (2.5YR 7/3) dense guano, wavy distinct boundary,

2-10 Dark reddish brown (5YR 3/2) extremely gravelly guano, angular, coarse to very coarse, basalt gravel "penguin stones", very sticky, wavy indistinct boundary,

10-20 Brown (7.5YR 3/2) extremely gravelly guano, angular coarse to very coarse basalt gravel "penguin stones", very sticky, wavy indistinct boundary,

20-40 Dark brown (10YR 3/4) extremely gravelly guano, angular coarse to very coarse basalt gravel "penguin stones", very sticky, smooth abrupt boundary,

40-50+ Dull yellowish brown (10YR 5/4) very gravelly silt, angular very coarse basalt gravel.

\section{Soil Map Unit 3}

The $0-5 \mathrm{~cm}$ depth comprised clean "penguin stones" overlying guano with "penguin stones" to a depth of $50 \mathrm{~cm}$ (Fig. 9 \& Fig. 10c). The guano was dry and decomposed with bird remains limited to feathers and bone material. Some relict mounds close to currently habited mounds did have some darker sticky guano material present, they lacked the compacted guano present on the surface at the inhabited sites. The clean gravels on the surface of formerly inhabited mounds indicate that compacted guano on the surface was washed off the surface stones by meltwater. The guano within the abandoned mounds had decomposed to a uniform colour and consistency. In January 2005 ice cement was at $80 \mathrm{~cm}$.

\section{Typical profile description}

Depth $(\mathrm{cm})$ Description

0-2 Reddish black (2.5YR 2/1) sub-rounded basalt gravel "penguin stones' pavement, irregular indistinct boundary,

2-12 Dark reddish brown (5YR 34) extremely gravelly guano, sub-rounded coarse to very coarse gravel "penguin stones", wavy indistinct boundary,

12-55 Very dark reddish brown (5YR 2/4) extremely gravelly guano, sub-rounded coarse to very coarse gravel "penguin stones", smooth sharp boundary,

55-80+ Reddish black (2.5YR 2/1) slightly gravelly coarse sand, sub-rounded coarse gravel, subrounded boulders.

\section{Soil Map Unit 4}

The soils of Unit 4 occur in the intermound areas on the main section of Seabee Hook (Fig. 9 \& Fig. 10b). The majority of the soil is the unweathered beach gravel and sand. The upper part comprised of a thin $(<2 \mathrm{~cm})$ layer of guano. In January 2005 ice cement was at $63 \mathrm{~cm}$ and the water table was at $45 \mathrm{~cm}$. 
Typical profile description

Depth $(\mathrm{cm})$ Description

0-2 Dull yellowish orange (10YR 6/3) slightly gravelly dense guano, reddish black (10R 1.7/1) coarse sand, sub-rounded medium basalt gravel, wavy abrupt boundary,

2-4 Yellowish grey $(2.5 \mathrm{Y} 5 / 1)$ very gravelly guano, reddish black (10R 1.7/1) sub-rounded medium to coarse basalt gravel, irregular diffuse boundary,

4-63+ Reddish black (10R 1.7/1) to black (5YR $1.7 / 1)$ very gravelly coarse sand, sub-rounded medium to coarse basalt gravel, sub-rounded basalt boulders.

\section{Soil Map Unit 5}

Unit 5 (Fig. 9) comprised layers of guano-dominant and gravel-dominant material to a depth of $60 \mathrm{~cm}$ (ice cement in January 2005). Gravel dominated layers appeared to be a result of storms where wave action deposited gravelly sand over guano runoff. Between storm events, runoff from mounds builds up a guano rich horizon. In January 2005 ice cement was at $60 \mathrm{~cm}$.

\section{Typical profile description}

Depth $(\mathrm{cm})$ Description

0-4 Light grey (2.5Y 8/2) to brownish black (5YR $2 / 1)$ to dull yellowish brown (10YR $5 / 3$ ) very slightly gravelly dense guano, coarse sand, sub-rounded very coarse basalt gravel, smooth abrupt boundary,

4-10 Brownish black (5YR 2/1) coarse sand, 5\% guano, wavy abrupt boundary,

10-30 Dull yellow (2.5Y 6/4) slightly gravelly guano, $50 \%$ coarse black $(7.5 \mathrm{YR} 2 / 1)$ sand, subrounded basalt boulders, wavy abrupt boundary,

30-50 Black (7.5YR 2/1) slightly gravelly coarse sand, $20 \%$ dull yellow $(2.5 \mathrm{Y} 6 / 4)$ guano, subrounded basalt boulders, smooth abrupt boundary,

50-60+ Dull yellowish brown (10YR 5/4) guano, 30\% coarse black (7.5YR 2/1) sand.

\section{Soil Map Unit 6}

The intermound areas on the fan (Fig. 9) contained angular gravel and cobble material. In January 2005 ice cement was at $60 \mathrm{~cm}$.
Typical profile description

Depth $(\mathrm{cm})$ Description

0-5 Light grey $(2.5$ Y $7 / 1)$ extremely gravelly dense guano, black (7.5YR 2/1) angular medium to very coarse basalt gravel, wavy indistinct boundary,

5-30 Dull yellowish orange (10YR 6/3) extremely gravelly silt, angular medium to very coarse basalt gravel, angular basalt boulders, wavy indistinct boundary,

30-60+ Dull yellowish orange (10YR 6/4) extremely gravelly silt, angular medium to very coarse basalt gravel, angular basalt boulders.

\section{Soil Map Unit 7}

The intermounds of Unit 7 occur below the steep scree slope in an area which receives meltwater runoff from the scree slope during the summer (Fig. 9). In January 2005 ice cement was at $60 \mathrm{~cm}$ and water table was at $45 \mathrm{~cm}$.

\section{Typical profile description}

Depth $(\mathrm{cm})$ Description

0-3 Brownish grey (10YR 5/1) sub-rounded very coarse basalt gravel pavement, sub-rounded basalt boulders, moss, algae and penguin eggshell, wavy indistinct boundary,

3-60+ Black (5YR 1.7/1) extremely gravelly coarse sand, sub-rounded coarse to very coarse basalt gravel.

\section{Soil Map Unit 8}

The angular basalt on the scree slope (Fig. 9) had minimal weathering, with some sandy material present below $5 \mathrm{~cm}$. In January 2005 ice cement was at $30 \mathrm{~cm}$.

\section{Typical profile description}

Depth $(\mathrm{cm})$ Description

0-5 Brownish grey (7.5YR 4/1) moderately gravelly medium to coarse sand, medium to very coarse angular basalt gravel, wavy diffuse boundary,

5-30+ Brownish grey (7.5YR 4/1) very gravelly medium to coarse slightly sandy loam, very coarse angular basalt gravel.

\section{Soil Map Unit 9}

Silt sized material comprised up to $10 \%$ of the $<2 \mathrm{~mm}$ fraction within the moraine profile (Fig. $9 \&$ Fig. 10d). The 
silt material was lighter in colour, distinguishing the moraine from the surrounding scree slope. In January 2005 ice cement was at $45 \mathrm{~cm}$.

\section{Typical profile description}

Depth $(\mathrm{cm})$ Description

0-2 Light grey (7.5YR 8/1) extremely gravelly sand, skua guano, brownish black (10YR 3/2) angular basalt boulders, wavy diffuse boundary,

2-45+ Dull yellowish brown (10YR 4/3) extremely gravelly sandy loam, coarse to very coarse brownish black (10YR 3/2) angular basalt gravel.

\section{Soil Map Unit 10}

In January 2005 an ice layer (possibly a glacic layer) was present at a depth of $40 \mathrm{~cm}$, with fine material accumulated above the ice (Fig. 9).

\section{Typical profile description}

Depth $(\mathrm{cm})$ Description

0-2 Dark brown (7.5YR 3/3) very coarse angular basalt gravel, indistinct smooth boundary,

2-35 Brownish black (7.5YR 2/2) extremely gravelly fine sandy loam, medium to very coarse angular basalt gravel, smooth indistinct boundary,

35-40+ Brown (7.5YR 4/3) slightly gravelly fine sandy loam, medium angular basalt gravel.

\section{Soil Map Unit 11}

The large angular boulders on the surface and the lack of relief distinguishes Unit 11 from surrounding areas (Fig. 9). In January 2005 ice cement was at $60 \mathrm{~cm}$.

\section{Typical profile description}

\section{Depth $(\mathrm{cm})$ Description}

0-2 Black (10YR 1.7/1) very coarse sub-rounded basalt gravel, very coarse angular basalt gravel, angular basalt boulders, wavy indistinct boundary,
2-60+

Black (10YR 2/1) moderately gravelly coarse sand, very coarse sub-rounded basalt gravel, sub-rounded basalt boulders.

\section{Soil Map Unit 12}

The areas of higher relief of the hummocky topography had considerable amounts of fine material (up to $30 \%$ silt) to a depth of $10 \mathrm{~cm}$ (Fig. 9). The fine material was possibly organic matter added from the numerous skua nests in the area. Skua guano was re-precipitated on the underside of some boulders. In January 2005 ice cement was at $70 \mathrm{~cm}$ and the water table was at $65 \mathrm{~cm}$.

\section{Typical profile description}

\section{Depth $(\mathrm{cm})$ Description}

0-2 Reddish black (10R 1.7/1) sub-rounded basalt boulder pavement, medium to very coarse subrounded basalt gravel, wavy distinct boundary,

2-10 Brownish black (5YR 2/2) very gravelly loamy sand, very coarse sub-rounded basalt gravel, sub-rounded basalt boulders, wavy distinct boundary,

10-65+ Reddish black (10R 1.7/1) medium to very coarse sub-rounded basalt gravel, sub-rounded basalt boulders.

\section{Soil Map Unit 13}

Disturbed areas comprised a range of soils modified by human activities. The soil properties varied depending on the nature of the disturbances which included bulldozing for construction of buildings and roads, rubbish dumps with soil bulldozed over garbage, hydrocarbon contaminated soil and artificial penguin mounds created with a bulldozer to encourage penguin nesting. Penguins had accepted these mounds and had re-created a new layer of "penguin stones" and guano, to a depth of $10 \mathrm{~cm}$ between the 1987 construction of the mounds and soil sampling in 2005. Beneath the "penguin stones", the bulldozed mounds comprised a mixture of aged guano, beach gravel and sand.

\section{Soil Map Unit 14}

In order to prevent damage to the plants in such an environmentally sensitive wetland area soil excavation and descriptions were not undertaken. 